\title{
定常確率過程による不確定性表現を用いた レベルセット法に基づくロバストトポロジー最適設計*
}

\author{
植田圭一 ${ }^{* 1}$, 乙守正樹 $* 2$, 小木曾望 ${ }^{* 3}$, 山田崇恭 $* 4$, 西脇眞二 $* 2$
}

\section{Level Set-Based Robust Topology Optimization Using Stationary Stochastic Process Model}

\author{
Keiichi UEDA*1, Masaki OTOMORI, Nozomu KOGISO, Takayuki YAMADA \\ and Shinji NISHIWAKI
}

${ }^{* 1}$ Department of Aerospace Engineering, Osaka Prefecture University 1-1 Gakuen-Cho, Naka-ku, Sakai, Osaka, 599-8531 JAPAN

\begin{abstract}
A robust topology optimization approach in consideration with random field uncertainty in loading condition is proposed in this paper. The proposed method integrates the level set-based topology optimization and the robust design method using stochastic process model. The stochastic process model is applied to describe the uncertainty of design parameters with nonuniform distribution in space with a reduced set of random variables. The robust optimization is formulated to minimize the robust compliance that is defined as a weighted sum of the expected value and the standard deviation of mean compliance under volume constraint. The standard deviation of mean compliance is approximated by the first-order sensitivity with respect to random variables that are described through the assumed spectral distributions from Wiener-Khintchine theorem. As a topology optimization, a level set-based approach incorporating a fictitious interface energy proposed by parts of the authors is applied. The method has several advantages to makes it possible to change structural topology as well as boundary shapes and to control the geometrical complexity of the optimum configuration qualitatively. Through numerical examples, the efficiency of the proposed robust topology optimization approach is demonstrated by comparing between the deterministic and robust optimum configurations.
\end{abstract}

Key Words : Optimum Design, Structural Design, Robustness, Stationary Stochastic Process, Structural Analysis

\section{1. 緒言}

ロバスト最適設計は, 材料物性や寸法, 荷重などの不確定性に対して, 設計指標の変動を最小化する設計法とし て広く用いられていて，その対象や手法は非常に多岐に渡る例えば,(1) (2)。例えば，構造設計問題に対しては，荷重 の変動に対して, その平均荷重に対する構造応答を最大化しつつ, 構造応答の変動を最小化するような問題が広く 考えられている.このとき, 構造応答の変動によってその最悪值が設計基準を逸脱しないように, それを制約条 件に加える方法がある。一方で, 荷重の変動の範囲を決め, その最悪值での性能が最良となる設計法も存在する. 特に, 変動が凸包でモデル化でき, 最悪值がその凸包の境界に存在するような問題は凸包モデル ${ }^{(3)}$ と呼ばれる.

本研究では，定めれた領域に作用する空間的な変動を有する分布荷重に対して，その平均值と分散が既知であ る場合に，剛性を最大化し，かつその変動を最小化する構造形態を求める問題を考える．ロバス卜最適設計問題 としては, 前者の考え方に基づき, 体積制約のもとで, 平均コンプライアンス (作用荷重による仕事) の平均值お よび分散の重み付き加重和を最小化するように定式化する.

\footnotetext{
* 原稿受付 2011 年 12 月 23 日

${ }^{* 1}$ 学生員, 大阪府立大学大学院工学研究科航空宇宙工学分野 (T 599-8531 大阪府堺市中区学園町 1-1)

*2 正員, 京都大学大学院 工学研究科 機械理工学専攻（ $\bar{T}$ 606-8501 京都府京都市左京区吉田本町）

*3 正員, 大阪府立大学大学院工学研究科航空宇宙工学分野 (T 599-8531 大阪府堺市中区学園町 1-1)

*4 正員, 名古屋大学大学院 工学研究科 機械理工学専攻 ( $\bar{T}$ 464-8603 愛知県名古屋市千種区不老町)

E-mail: k-ueda@aero.osakafu-u.ac.jp
} 


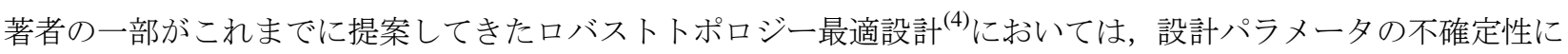
対して空間的な変動を考慮せず, 空間に対して一様に変動するものとして取り扱ってきた. これに対し, 本研究で は, 空間的な変動を考慮することで, 実際の不確定現象により近いモデルを構築する，そのような変動のモデル 化として, 有限要素モデルの要素 (節点) ごと, あるいは区分ごとに乱数を用いて独立な不確定性を与える方法が 考えられる. しかし, そのようなモデル化は, 確率変数が増大寸る問題のほかに, 隣り合う領域でパラメータが 極端に変化することがあり，モデル化としての妥当性に疑問が残る.

本研究では, 荷重の空間的な不確定性を表すために, 確率過程 ${ }^{(5)}$ 適用する。確率過程は空間的な変動を少ない 確率変数でモデル化できる利点があり, 中桐らが開発した確率有限要素法 ${ }^{(6)}$, さらには, 確率過程によるモデル化 に特化したスペクトル確率有限要素法 ${ }^{(7)}(8)$ においても広く用いられている. 本研究で扱う空間的な不確定性は定常 確率過程で表現できる場合に限定するが，これらの手法を適用することで，荷重などの入力成分の空間変動をパ ワースペクトルで表すだけでなく, 解析によって得られる変位や応力などの出力の空間変動をパワースペクトル として表すことで, 入力の空間変動が出力の空間変動におよぼす影響を定量的に評価することができる.

なお, 構造形態を求めるトポロジー最適設計としては, 山田らが提案している境界移動と形態変更とを可能と

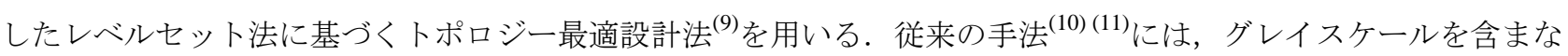
い明確な境界が得られる利点があるが，設計領域に穴が創出されるような形態変更が許容されない問題があった。 これに対して, 山田らの提案した手法 ${ }^{(9)}$ は, フェーズフィールド法 ${ }^{(12)}{ }^{(13)}$ の考え方を導入し, 仮想的な表面張力項 を含むエネルギー汎関数の最小化問題に帰着させることにより, 穴の創出を可能とし, さらには構造形態の幾何 学的な複雑さを定性的に表すことも可能である. すなわち, 従来の手法で必要であった穴を多数あけた初期設計 形態が不要となり, 設計領域すべてを材料領域としても合理的な最適形態が得られる.また, 最適形態が初期設 計形態への依存性が小さい利点もある.

なお，近年，Chen らが，不確定性表現に確率過程を利用したレベルセット法に基づくロバストトポロジー最適 設計に関する研究を発表している(14).この研究のトポロジー最適設計法は従来のレベルセット法を用いているの に対し, 本研究では山田らの提案した手法を用いている点やロバスト最適形態への収束性, 最適形態の妥当性の 面で異なっている.

以下， 2 章ではトポロジー最適設計について概説し，その後，3 章でロバスト最適設計について説明するととも に, 確率過程を利用した確率変数の表現法について説明する. 4 章でロバストトポロジー最適設計の定式化および 感度解析について説明するとともに, 実装のためのアルゴリズムを示す. 5 章では, 数值計算例を示す. 特に, 確 定的な最適形態とロバスト最適形態に対して, 入力として与える荷重の空間変動が出力である平均コンプライア ンスの空間変動におよぼす影響をパワースペクトルを介して比較することにより，本論文で提案する手法の妥当 性を検証する。

\section{2. トポロジー最適化}

\section{$2 \cdot 1$ レベルセット法による形状表現を用いたトポロジー最適化}

定められた固定設計領域 $D$ において, 物体により占められる領域 $\Omega$ (以下, 物体領域) を決定する構造形態最適 化問題を考える. 寸なわち, 目的汎関数を $F$, 体積制約を制約汎関数 $G$ で表す構造最適化問題を次式で定義する.

$$
\begin{aligned}
& \inf _{\phi}: F(\Omega(\phi))=\int_{\Omega} f(\boldsymbol{x}) \mathrm{d} \Omega \\
& \text { subject to }: G(\Omega(\phi))=\int_{\Omega} \mathrm{d} \Omega-V_{\max } \leq 0
\end{aligned}
$$

ここで, $f(\boldsymbol{x})$ は目的汎関数の被積分関数で, $V_{\max }$ は許容される体積の上限值である.

レベルセット法では, 図 1 に示すように, レベルセット関数と呼ばれるスカラー関数 $\phi(x)$ を用いて, そのゼロ 等位面によって物体境界を陰的に表現する。すなわち次式に示すように, 物体領域において正, 空洞領域におい 


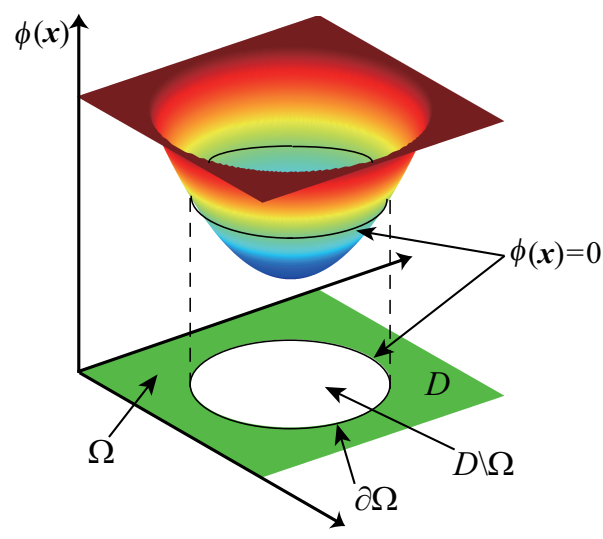

Fig. 1 Fixed design domain $D$ and level set function $\phi$

て負，物体の境界ではゼロとなるレベルセット関数を用いて物体の形状表現を行う.

$$
\begin{cases}0<\phi(x) \leq 1 & \text { if } \quad \forall \boldsymbol{x} \in \Omega \backslash \partial \Omega \\ \phi(x)=0 & \text { if } \quad \forall \boldsymbol{x} \in \partial \Omega \\ -1 \leq \phi(x)<0 & \text { if } \quad \forall \boldsymbol{x} \in D \backslash \Omega\end{cases}
$$

ここで， $\boldsymbol{x}$ は固定設計領域の座標である。なお，式(3)において，レベルセット関数に上限值と下限值を導入して いるのは，後述するように，目的汎関数に付加する仮想的な界面エネルギーを導入するためである.

このレベルセット関数 $\phi(x)$ は固定設計領域 $D$ 内の至る所で不連続性を持つことを許容している.このことは, 得られる最適構造が至る所で不連続となる解を許容することになり，いわゆる不適切な (ill-posed) 問題となるた め，なんらかの方法で最適化問題を適切な (well-posed) 問題にする正則化を必要とする. 従来の手法では, 正則化 法として均質化法 ${ }^{(15)}(16)$ が利用されてきた。しかしながら, 形状を表現する関数が異なるため, 本手法には適用す ることができない.

そこで, 本研究では, フェーズフィールド理論 ${ }^{(12)}{ }^{(13)}$ の定式化で利用されている界面エネルギーを導入すること で，問題の正則化を行う。この方法の基本的な考え方は，目的汎関数にレベルセット関数の勾配の大きさによって 表現される仮想的な界面エネルギーを加え，それを正則化された目的汎関数 $F_{R}$ とすることである.

$$
F_{R}(\Omega(\phi))=\int_{\Omega} f(\boldsymbol{x}) \mathrm{d} \Omega+\int_{D} \frac{1}{2} \tau|\nabla \phi|^{2} d \Omega
$$

ここで， $\tau$ は仮想的な界面エネルギーの寄与度を表すパラメータであり，正則化係数と呼ぶ．界面エネルギーは周 囲長が短いほど小さな值をとるため，正規化係数が大きいほど，周囲長の短い単純な構造形態が得られる，逆に正 規化係数が小さいほど界面エネルギーの影響が効かなくなるため, 周囲長の長い複雑な構造形態が得られる。つ まり，式 (4)の第 2 項は陰的な周長制約とみな寸ことができる。したがって，正則化係数の設定值により，最適構 造の幾何学的な複雑さを定性的に設定することが可能となる．詳細は文献(9)を参照されたい.

次に，ラグランジュ未定乗数法を用いて，無制約問題に置き換える。すなわち，ラグラジュアンを $\bar{F}$, 式 (2) に 関するラグランジュ乗数を $\lambda$ とすれば，上述の最適化問題は次式となる.

$$
\underset{\phi}{\operatorname{Minimize}}: \bar{F}(\Omega(\phi), \phi)=\int_{\Omega}(f(\boldsymbol{x})+\lambda) \mathrm{d} \Omega-\lambda V_{\max }+\int_{D} \frac{1}{2} \tau|\nabla \phi|^{2} \mathrm{~d} \Omega
$$

本研究では上式を解くことにより最適構造を得る.

\section{$2 \cdot 2$ 時間発展方程式によるレベルセット関数の更新}

本研究では, 最適化問題を時間発展方程式を解く問題へと置き換えることにより, 設計変数であるレベルセット 関数を更新する. まず, 仮想的な時間 $t$ を導入し, レベルセット関数を更新させる駆動力は, 次式に示すように, ラグラジュアン $\bar{F}$ の勾配に比例するものと仮定する.

$$
\frac{\partial \phi}{\partial t}=-K(\phi) \frac{\delta \bar{F}}{\delta \phi}
$$




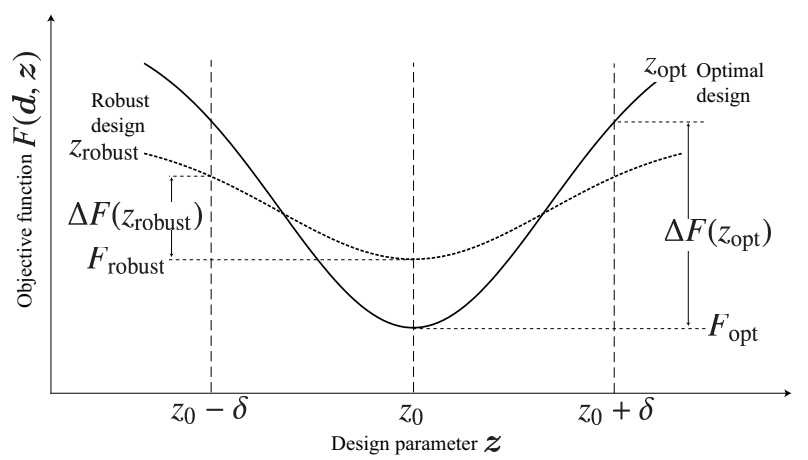

Fig. 2 Concept of robust optimization

ここで, $K(\phi)(>0)$ は比例定数, $\delta \bar{F} / \delta \phi$ はラグラジュアン $\bar{F}$ の汎関数微分を表す. 式(6)に式(5)を代入し，境界 条件として，物体領域境界であることが指定されている境界 $\partial D_{N}$ においてはディリクレ境界条件，その他の境界 においてはノイマン境界条件を与え，固定設計領域外部からの影響がないことを表現する．以上より，時間発展 方程式は反応拡散方程式系として次式で表される。

$$
\begin{array}{rlrlrl}
\frac{\partial \phi}{\partial t} & =-K(\phi) & \left(\frac{\delta \bar{F}}{\delta \phi}-\tau \nabla^{2} \phi\right) \\
\frac{\partial \phi}{\partial n} & =0 & & \text { on } & & \partial D \backslash \partial D_{N} \\
\phi & =1 & & \text { on } & & \partial D_{N}
\end{array}
$$

\section{3.ロバスト設計}

\section{$3 \cdot 1$ ロバスト設計の定式化}

ロバスト設計は，設計変数や設計パラメータの不確定性が目的関数や制約条件におよぼす影響を考慮した設計 法である。そのために，設計パラメータ等の変動が目的関数や制約条件におよぼす影響をそれらの標準偏差を用 いてモデル化する。一般的には，目的関数および制約条件をそれぞれの期待值および標準偏差の重み付き加重和 として, 最適設計問題を定式化する ${ }^{(1)}$. 本研究では, ロバスト設計法として, 感度解析に基づく手法 ${ }^{(17)}$ を用いる. これは，目的関数および制約条件の平均值まわりの変動を，設計変数および設計パラメータの一次近似として表 し，その標準偏差を感度解析によって評価する方法である。

本研究においては負荷荷重などの設計パラメータの変動を考慮するだけであり, 設計変数は構造境界を表すレ ベルセット関数の変動は考慮しない。また，制約条件は構造の体積制約のみであり，これは構造形態のみに関係す るため，その変動は考慮しないものとする.

設計変数を $\boldsymbol{d}=\left[d_{1}, \cdots, d_{n_{d}}\right]^{T}\left(n_{d}\right.$ は設計変数の数 $)$, 設計パラメータを $\boldsymbol{z}=\left[z_{1}, \cdots, z_{n_{z}}\right]^{T}$ ( $n_{z}$ は設計パラメータの数 $)$ と表し，目的関数の平均值を $\mathrm{E}[\cdot]$ ，その分散を $\operatorname{Var}[\cdot]$ とすると， ロバス卜性を考慮した目的関数は次式で定式化で きる.

$$
\text { Minimize : } \quad F_{\text {robust }}(\boldsymbol{d})=\mathrm{E}[F(\boldsymbol{d}, \boldsymbol{z})]+\alpha \sqrt{\operatorname{Var}[F(\boldsymbol{d}, \boldsymbol{z})]}
$$

このロバスト性を考慮した目的関数を最小化することで，目的関数の平均值および標準偏差の加重和を最小化す ることをめざす．ここで， $\alpha$ は正の重み係数であり， $\alpha$ の值を大きくするほど，目的関数の標準偏差の影響を考慮 することになる．ただし，その影響は問題設定に依存するため，適切な值を設定するための基準を定量的に記述 することは困難である。

図 2 にロバスト設計の概念図を示す， $z_{\mathrm{opt}}$ と $z_{\text {robust }}$ はそれぞれ確定的手法とロバス卜設計で得られた目的関数の 值を示している. 設計パラメータ $d$ が $\delta$ だけ変化したとき, $z_{\mathrm{opt}}$ と $z_{\text {robust }}$ を比較すると, $z_{\text {robust }}$ の方が目的関数の 変化が小さくなっていることがわかる．このように，ロバスト性を考慮した目的関数を用いることで，設計パラ メータの変動に対して頑強な設計解を求めることをめざす，なお，一般的には，変動によって設計指標の基準值を 冕脱することを防ぐために，それを制約条件に追加する．しかし，本研究では平均コンプライアンスに最大值を 設定することが一般的ではないために，その制約は課していない. 


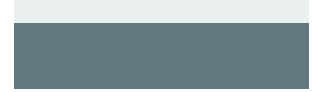

(a) Uniform

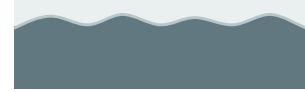

(b) Regularly variable

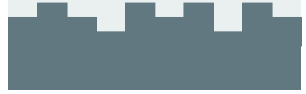

(c) Descretized random

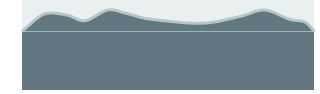

(d) Random process

Fig. 3 Spatial variability model

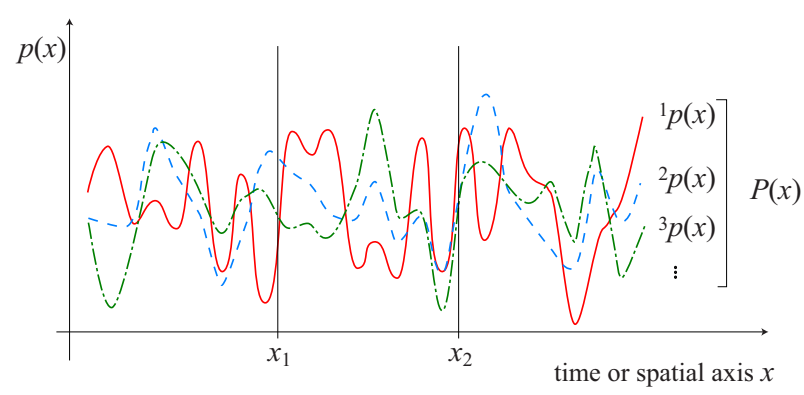

Fig. 4 Stochastic process

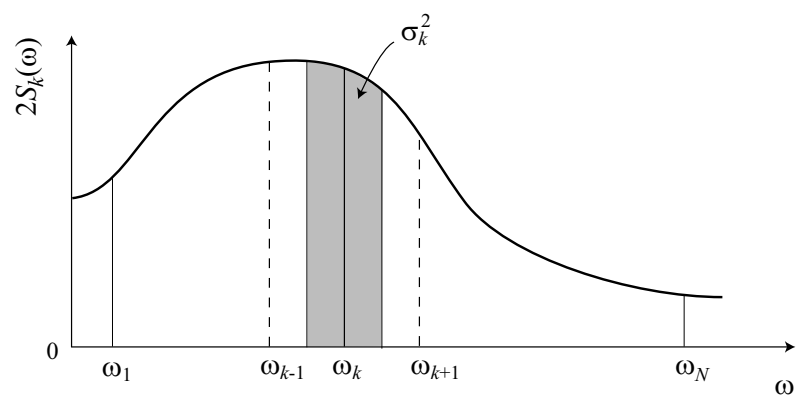

Fig. 5 Power spectrum

また，一次近似を用いると目的関数の平均值と分散は次式で近似できる ${ }^{(4)}$.

$$
\begin{aligned}
\mathrm{E}[F(\boldsymbol{d}, \boldsymbol{z})] & \approx F(\mathrm{E}[\boldsymbol{d}], \mathrm{E}[\boldsymbol{z}]) \\
\operatorname{Var}[F(\boldsymbol{d}, \boldsymbol{z})] & \approx \sum_{i=1}^{n_{z}}\left(\frac{\partial F}{\partial z_{i}}\right)^{2} \operatorname{Var}\left[z_{i}\right]
\end{aligned}
$$

なお，本研究では設計変数の変動を考慮していないため，分散の導出においては設計パラメータの変動のみを考 慮している。また，この一次近似は感度解析を用いるために計算コストを低く抑えられる利点があるが，分散が 大きい場合は近似精度が悪化する可能性がある。

\section{2 確率過程を用いた不確定性のモデル化}

設計パラメータの空間的な変動を表すモデルには，いくつかの種類がある．最も単純なモデルとして，一様に 変化させる方法 (図 3(a)) や規則的に変化させる方法 (図 3(b)) がある. これは少ない変数でモデル化できる利点が あるが，空間的な変動を扱うには不十分である。また，離散化した要素ごとに変化を与える方法 (図 3(c)) は実装 が容易であるが，多くの変数を要することと空間的な相関を表現できない点で問題がある。これに対して，空間 的な変動に対する統計的性質 (パワースペクトルや自己相関関数など ${ }^{(5)}$ ) がわかっている場合は, 図 $3(\mathrm{~d})$ に示すよ うに，その不規則現象を確率過程 ${ }^{(5)}$ を用いてモデル化することにより，隣接部との相関を考慮した現実性の高いモ デルを比較的少ない変数で実現できる利点がある。そのため, 確率過程は, 地震荷重や波浪荷重のような時系列 における不確定性のモデル化で広く用いられている(6). また, 鋼板の腐食による板厚摩耗など, 時間だけでなく空 間的な不確定性のモデル化にも用いられている(7)(8).

空間変動の確率過程 $P(x)$ が定常過程であるとき, Wiener-Khintchine $の$ 定理 ${ }^{(5)} よ り$, 自己相関関数 $R_{p p}(\rho)$ とパ ワースペクトル密度 (両側スペクトル) $S(\omega)$ はフーリエ変換を通して, 次式で示す関連付けられる.

$$
\begin{aligned}
R_{p p}(\xi) & =\mathrm{E}[P(x) P(x+\xi)]=\mathrm{E}[P(0) P(\xi)]=\int_{-\infty}^{\infty} S(\omega) \exp (i \omega \xi) \mathrm{d} \omega \\
S(\omega) & =\int_{-\infty}^{\infty} R_{p p}(\xi) \exp (-i \omega \xi) \mathrm{d} \xi
\end{aligned}
$$

ここで， $\omega$ は角振動数である。また，Wiener-Khintchineの定理より，確率過程とパワースペクトルの関係は次式 で表される.

$$
P(x)=\int_{-\infty}^{\infty} \sqrt{S(\omega)} \exp (-i \omega x+i \theta) \mathrm{d} \omega
$$

ここで， $\theta$ は位相角であり，任意の值をとる。このことは，パワースペクトルが等しくても，異なる位相角 $\theta$ を もつ確率過程の実現值 $\left.{ }^{i} p(x), i=1,2, \cdots, \infty\right)$ が，図 4 に示すように無限に存在することを意味する．また，式 $(13)$ 


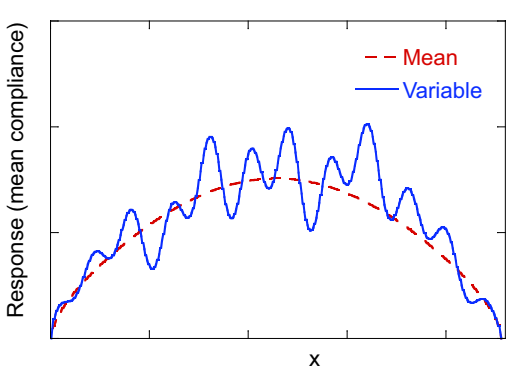

(a) Mean and variable response

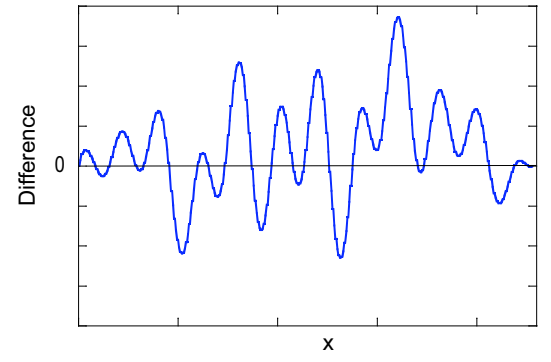

(b) Difference

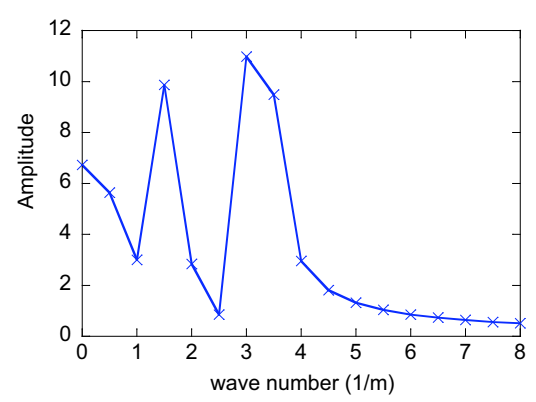

(c) Power spectrum evaluated by FFT.

Fig. 6 Power spectrum of spatial variated response

より, $P(x)$ の 2 乗平均 $\mathrm{E}\left[P(x)^{2}\right]$ は次式で表される.

$$
\mathrm{E}\left[P(x)^{2}\right]=\int_{-\infty}^{\infty} S(\omega) \mathrm{d} \omega=R_{p p}(0)
$$

これより, $P(x)$ の分散は自己相関関数から求めることができる.

\section{$3 \cdot 3$ 不確定性を有する分布荷重のモデル}

本研究では, 空間的変動を有する分布荷重を確率過程を用いてモデル化するために, 周波数領域で離散化 $\left(\omega_{1}, \omega_{2}, \cdots, \omega_{N}\right)$ する. このとき, $P(x)$ の分散 $\sigma^{2}$ は, 図 5 に示すように, 両側スペクトル $S\left(\omega_{k}\right)$ を用いて, 次 式で表すことができる.

$$
\begin{aligned}
\sigma_{1}^{2} & =2 \int_{0}^{\left(\omega_{1}+\omega_{2}\right) / 2} S_{1}(\omega) \mathrm{d} \omega \\
\sigma_{k}^{2} & =2 \int_{\left(\omega_{k-1}+\omega_{k}\right) / 2}^{\left(\omega_{k}+\omega_{k+1}\right) / 2} S_{k}(\omega) \mathrm{d} \omega, \quad(k=2, \cdots, N-1) \\
\sigma_{N}^{2} & =2 \int_{\left(\omega_{N-1}+\omega_{N}\right) / 2}^{\infty} S_{N}(\omega) \mathrm{d} \omega
\end{aligned}
$$

確率過程の分散 $\sigma^{2}$ はこれらの分散の和として表される.

$$
\sigma^{2}=\sum_{k=1}^{N} \sigma_{k}^{2}
$$

これを用いると，確率過程は標準偏差 $\sigma_{i}$ を用いて，次式で表すことができる.

$$
P(x)=\sum_{k=1}^{N} \sigma_{i} \cos \left(\omega_{k} x+\theta_{k}\right)
$$

各振動数に対して任意の位相角 $\theta_{k}$ を有する実現波は, 同一の確率過程として表される. なお, 表面力 $\boldsymbol{t}$ の空間分 布は式 (21) に平均值 $\mu$ を加えることで得られる.

\section{$3 \cdot 4$ 空間的に変動する荷重に対する構造応答の評価}

空間的な確率過程でモデル化した入力荷重に対する構造応答の空間的変動を評価するために，構造応答のパワー スペクトルを利用する.

本研究では, 空間的に変動する荷重に対する平均コンプライアンスを構造応答として考える. 空間変動荷重を 一様な平均荷重と平均ゼロの変動成分とに分けると, 線形構造に対する構造応答は, 平均入力に対する応答と変 動入力に対する応答との重㸚合わせとモデル化できる.したがって, 変動を含む全荷重に対する応答 (図 6(a) に示 寸実線) から, 平均荷重に対する応答 (図 6(a) の破線) を差し引くことで, 図 6(b) に示すような平均ゼロの変動荷 重に対する構造応答が得られ，これを構造応答の変動成分とみなす.

そして, 構造応答の変動成分にフーリエ変換を施すことで, 図 6(c) に示すようなパワースペクトルを求めるこ とができる，パワースペクトルは変動の振幅成分を表しているため, 荷重変動の個々の実現波における位相角の 
影響を排除した構造応答の波数成分を検討することができる. 本研究では, 空間変動を有する荷重入力に対する ロバスト性をこのパワースペクトルを用いて考察する.

ここで, 変位や平均コンプライアンスなどの構造応答は, 変位境界条件部 $\left(\Gamma_{u}\right)$ では, 空間変動荷重の位相角に かかわらず, 変位自体がゼロとなるために変動が生じない.したがって, 異なった位相角を有する空間変動荷重に 対して, 構造応答のパワースペクトルが必ずしも一致するわけではない. しかしながら， $\Gamma_{u}$ の周辺では変位その ものが小さいために, 変位の変動も小さく, 空間変動荷重の位相角が構造応答の変動におよぼす影響は小さいも のと考えられる. そこで, 本研究では, 構造応答のパワースペクトル特性によって, 入力荷重の変動の影響を考 察することとする.

\section{4. 剛性最大化ロバスト設計の定式化}

\section{$4 \cdot 1$ 剛性最大化問題}

線形弾性体で構成される物体領域と空洞領域で構成される固定設計領域 $D$ に対し，境界 $\Gamma_{u}$ を完全拘束し，境界 $\Gamma_{t}$ に表面力 $\boldsymbol{t}$, 物体領域 $\Omega$ に物体力 $\boldsymbol{b}$ を作用させる構造問題を考える. ただし, 境界 $\Gamma_{u}$ は, 固定設計領域境界 $\partial D$ に固定されているものとする。 このとき, 体積制約の下で平均コンプライアンスを最小化させる構造最適化問 題は次式のように定式化される.

$$
\begin{aligned}
\inf _{\Omega} & F(\Omega)=l(\boldsymbol{u}) \\
\text { subject to } & a(\boldsymbol{u}, \boldsymbol{v})=l(\boldsymbol{v}) \quad \text { for } \quad \boldsymbol{u} \in U \quad \forall \boldsymbol{v} \in U \\
& G(\Omega)=\int_{\Omega} \mathrm{d} \Omega-V_{\max } \leq 0
\end{aligned}
$$

ここで, $a(\boldsymbol{u}, \boldsymbol{v})$ はひずみエネルギー, $l(\boldsymbol{v})$ は平均コンプライアンスであり, それぞれ次式で定義される.

$$
\begin{aligned}
& a(\boldsymbol{u}, \boldsymbol{v})=\int_{\Omega} \boldsymbol{\varepsilon}(\boldsymbol{u}): \boldsymbol{E}: \boldsymbol{\varepsilon}(\boldsymbol{v}) \mathrm{d} \Omega \\
& l(\boldsymbol{v})=\int_{\Gamma_{t}} \boldsymbol{t} \cdot \boldsymbol{v} \mathrm{d} \Gamma+\int_{\Omega} \boldsymbol{b} \cdot \boldsymbol{v} \mathrm{d} \Omega
\end{aligned}
$$

なお， $\boldsymbol{\varepsilon}$ はひずみテンソル，E は弾性テンソルを表し，Uは以下の式にて定義される変位関数空間である.

$$
U=\left\{\boldsymbol{v}=v_{i} e_{i}: v_{i} \in H^{1}(D)\right\} \quad \text { with } \quad \boldsymbol{v}=0 \text { on } \Gamma_{u}
$$

次に，上の最適化問題に関する KKT 条件を導くとともに，その結果から，レベルセット関数 $\phi$ の更新に必要な 関数 $f(\boldsymbol{x})$ を与える. 上述の定式化より, ラグラジュアン $\bar{F}(\Omega)$ は, ラグランジュ乗数 $\lambda$, 随伴変位場 $\boldsymbol{v}$ を用いて 以下のように記述される.

$$
\bar{F}(\Omega)=l(\boldsymbol{u})+a(\boldsymbol{u}, \boldsymbol{v})-l(\boldsymbol{v})+\lambda G(\Omega)
$$

式(28)を用いて, KKT 条件を導けば，次式となる.

$$
\begin{array}{rrrr}
\delta \bar{F}(\Omega) & =0, & a(\boldsymbol{u}, \boldsymbol{v})-l(\boldsymbol{v}) & =0 \\
\lambda G(\Omega) & =0, & \lambda \geq 0, & G(\Omega) \leq 0
\end{array}
$$

ここで, 随伴変位場 $\boldsymbol{v}$ を次式で定義することにより, 最適化問題を自己随伴問題とする.

$$
a(\boldsymbol{v}, \boldsymbol{u})=l(\boldsymbol{u}) \quad \text { for } \quad \forall \boldsymbol{u} \in U \quad \boldsymbol{v} \in U
$$

式 (28), (29), (30)より, ラグラジュアン $\bar{F}(\Omega)$ は次式となる.

$$
\bar{F}(\Omega)=l(\boldsymbol{u})+\lambda G(\Omega)=a(\boldsymbol{u}, \boldsymbol{u})+\lambda G(\Omega)=\int_{\Omega}(\varepsilon(\boldsymbol{u}): \boldsymbol{E}: \varepsilon(\boldsymbol{u})+\lambda) \mathrm{d} \Omega-\lambda V_{\max }
$$

したがって, ラグラジュアンを与える被積分関数 $\bar{f}(\boldsymbol{x})$ は次式となる.

$$
\bar{f}(\boldsymbol{x})=\boldsymbol{\varepsilon}(\boldsymbol{u}): \boldsymbol{E}: \boldsymbol{\varepsilon}(\boldsymbol{u})+\lambda
$$




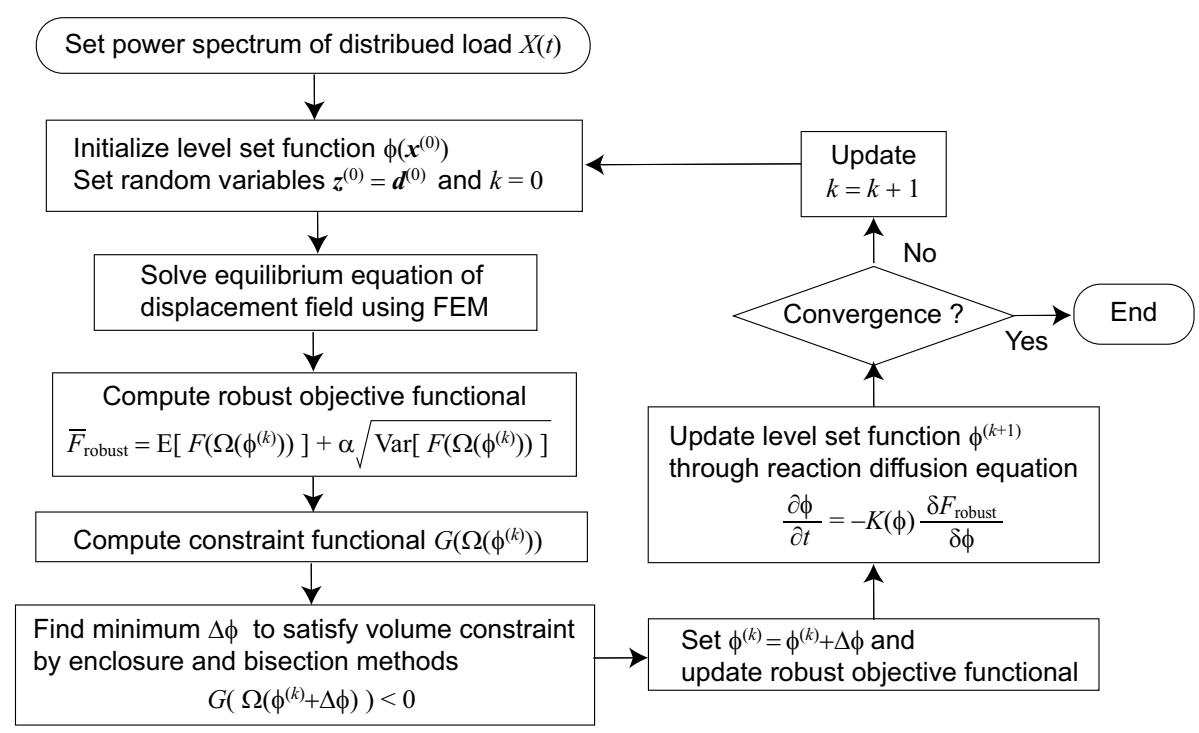

Fig. 7 Flowchart of robust topology optimization

\section{$4 \cdot 2$ ロバスト最適設計への定式化と感度解析}

式 (10) で示したロバスト最適設計の目的関数に対して, 式 (31) で示した剛性最大化問題のラグランジュアンの 平均および標準偏差を用いて，ロバスト最適設計問題におけるラグランジュアンを次式で定義する.

$$
\begin{aligned}
\bar{F}_{\text {robust }}(\Omega, \boldsymbol{P}) & =[l(\boldsymbol{u}, \boldsymbol{P})+\lambda G(\Omega)]-\lambda V_{\max }+\alpha \sqrt{\operatorname{Var}[\bar{F}]} \\
& =\int_{\Omega}(\boldsymbol{\varepsilon}(\boldsymbol{u}): \boldsymbol{E}: \boldsymbol{\varepsilon}(\boldsymbol{v})+\lambda) \mathrm{d} \Omega-\lambda V_{\max }+\alpha \sqrt{\left(\frac{\partial \bar{F}}{\partial \boldsymbol{t}}\right)^{2} \operatorname{Var}[\boldsymbol{t}]}
\end{aligned}
$$

なお, 本研究では, 荷重の変動のみを考慮し, 体積制約における設計変数の変動を考慮しないため, ラグランジュ アン $\bar{F}$ の分散は目的関数 $F$ の分散と等しい.

表面力 $\boldsymbol{t}(x)$ の空間変動は，確率過程を用いて次式のパワースペクトルで表現する.

$$
\boldsymbol{t}(x)=\boldsymbol{\mu}(x)+\sum_{k=1}^{N} \sigma_{i} \cos \left(\omega_{k} x+\theta_{k}\right)
$$

ここで, $\mu(x)$ は平均荷重である.

パワースペクトルを離散化した空間振動数 $\omega_{k}$ に対する目的関数の微係数は次式で求められる.

$$
\frac{\partial \bar{F}}{\partial \boldsymbol{t}}=\int_{\Gamma} \boldsymbol{u} \mathrm{d} \Gamma \cdot \sum_{k}\left[\sqrt{S\left(\omega_{k}\right) \Delta f_{k}} \sin \left(\bar{\omega}_{k} x+\theta_{k}\right)\right]
$$

さらに，形状更新に用いる感度をロバス卜設計における感度とするために，式(33)より得られる次式を形状更新 の感度に加える.

$$
\frac{\partial \sqrt{\operatorname{Var}[\bar{F}]}}{\partial \phi}=\frac{\partial \sqrt{\operatorname{Var}[\bar{F}]}}{\partial \boldsymbol{u}} \frac{\partial \boldsymbol{u}}{\partial \phi}=\frac{1}{\sqrt{\operatorname{Var}[\bar{F}]}} \sum_{k}\left[\left(\int_{\Gamma} \boldsymbol{u} \mathrm{d} \Gamma \cdot \frac{\partial \boldsymbol{t}}{\partial \theta_{k}}\right)\left(\int_{\Gamma} \mathrm{d} \Gamma \cdot \frac{\partial \boldsymbol{t}}{\partial \theta_{k}}\right) \sqrt{\operatorname{Var}\left[\theta_{k}\right]}\right] \frac{\partial \boldsymbol{u}}{\partial \phi}
$$

ここで， $\theta_{k}$ は，離散化した各空間振動に対する位相角であり，その変動は $[0,2 \pi]$ の一様分布としている.

\section{$4 \cdot 3$ 実装}

数值実装上，体積制約に対する各ステップの数值誤差は微小であるものの，繰り返し計算を行うことにより，そ の数值誤差が累積されることがある. これを修正するために, 次式を満たす微小值 $\Delta \phi(x)$ の最小值を求め, 新た に $\phi(x)+\Delta \phi(x)$ をレベルセット関数の值とするように修正する.

$$
G(\Omega(\phi(x)+\Delta \phi(x))) \leq 0
$$




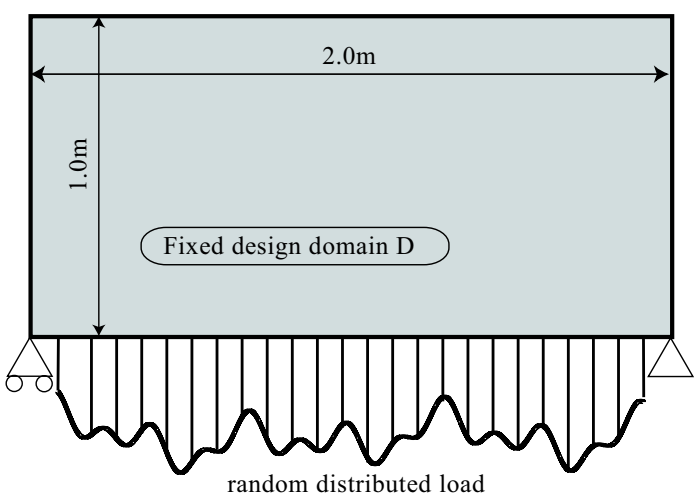

Fig. 8 Design domain and boundary conditions in example

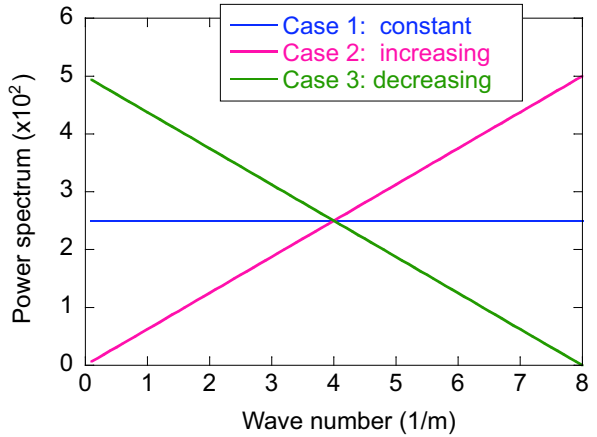

Fig. 9 Load cases described by power spectrum

Table 1 Spacial distribution of distributed load

\begin{tabular}{l|ccccccc}
\hline Wave number $(1 / m)$ & $f_{1}$ & $f_{2}$ & $f_{3}$ & $f_{4}$ & $f_{5}$ & $f_{6}$ & $f_{7}$ \\
\hline & 0.0625 & 0.1875 & 0.375 & 0.75 & 1.5 & 3.0 & 6.0 \\
\hline$*: f_{i}=2 \pi \omega_{i}$ & & & & & & &
\end{tabular}

\begin{tabular}{c|lllllll}
\hline Coefficient of variation & $\sigma_{1} / \mu$ & $\sigma_{2} / \mu$ & $\sigma_{3} / \mu$ & $\sigma_{4} / \mu$ & $\sigma_{5} / \mu$ & $\sigma_{6} / \mu$ & $\sigma_{7} / \mu$ \\
\hline Case 1 & 0.0125 & 0.0125 & 0.01768 & 0.250 & 0.03536 & 0.050 & 0.07071 \\
Case 2 & 0.001561 & 0.002704 & 0.005408 & 0.01082 & 0.02165 & 0.04324 & 0.08660 \\
Case 3 & 0.01761 & 0.01746 & 0.02439 & 0.03365 & 0.04506 & 0.05586 & 0.050 \\
\hline
\end{tabular}

本研究では，ロバストトポロジー最適設計における性能比較のために，実質的には体積がその上限值 $V_{\max }$ に等し くなること，つまり，体積制約が活性化することが望まれる，そのために，本研究では式 (37) が等式成立するよ うに，囲い込み法と二分法を利用する.

これを考慮したロバストトポロジー最適設計のフローを図 7 に示す.

\section{5. 数 值 例}

図 8 で表される板厚 $1.0 \times 10^{-2} \mathrm{~m}$ で一定の $2.0 \mathrm{~m} \times 1.0 \mathrm{~m}$ の長方形設計領域 $D($ ヤング率 $210 \mathrm{GPa}$, ポアソン比 0.33$)$ に対して, 両端を変位固定 (境界 $\Gamma_{u}$ ) し, 長方形の底辺 $\left(\right.$ 境界 $\Gamma_{t}$ ) から空間変動を有する平均 $1 \times 10^{5} \mathrm{~N} / \mathrm{m}$ の下向き 分布荷重が負荷されているものとし，その構造解析においては固定設計領域を 12800 要素 $(80 \times 160)$ に離散化す る. 最適設計においては，構造として妥当な形態となるように，体積上限值を $1 \mathrm{~m}^{3}$ (固定設計領域の $50 \%$ )，正則化 係数 $\tau$ を $1.0 \times 10^{-5}$ に設定する.

分布荷重の空間変動として，単位長さあたりの波数が 8 までを考慮し，図 9 に示す 3 つの荷重ケース ( (i) スペクトルが一定の場合，(ii) 波数に対して増加する場合，(iii) 波数に対して減少する場合)を考える.いずれ

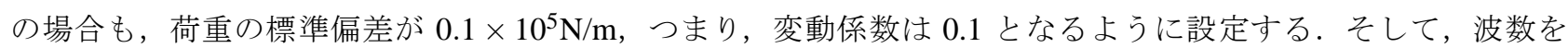
0 0.125 0.25 0.50 1.0 2.0 4.0 8.0 (1/m) の 7 区間で分割し，7つの確率変数で表すことにする.このときの 荷重確率過程モデルの波数および各波数に対する変動係数 $(=\sigma / \mu)$ を表 1 に示す. 各ケースに対して，異なる位 相角を有する荷重の実現波の例を図 10 に示す.

\section{$5 \cdot 1$ 最適形態の比較と収束履歴}

最適形態の比較のために，まずは，境界 $\Gamma_{f}$ において均等分布荷重が負荷している場合の確定的な最適設計で得 られた最適形態および重み係数を $\alpha=25$ としたロバスト設計で得られた最適形態を図 11 に示す.ロバスト形態 のケース 1 は，確定解(図 11(a)) と比べ，アーチは低くなり，柱の本数が増えるとともに柱の間隔が狭くなってい ることがわかる．これにより，分布荷重の変動に対してロバストな形態と考えることができる．これに比べ，ケー ス 2 は確定的な最適形態とよく似た形態となる。ケース 2 では，比較的に波数の多い荷重が支配的になるために， 


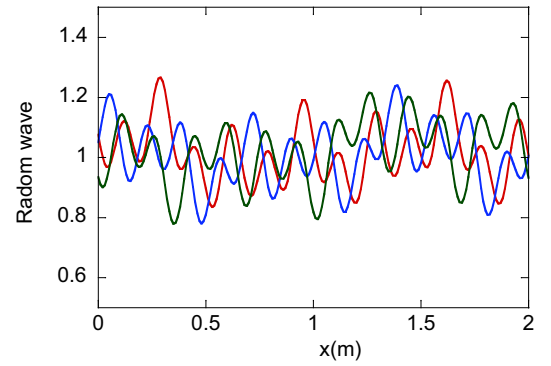

(a) Case 1 (constant)

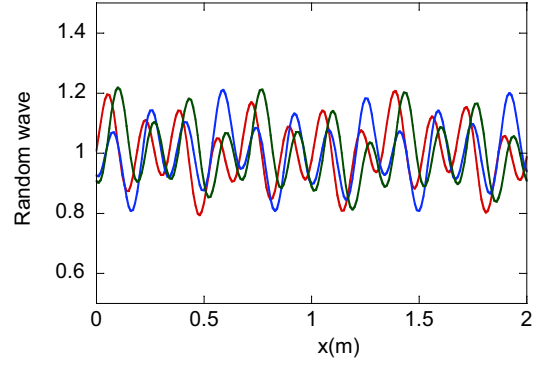

(b) Case 2 (increasing)

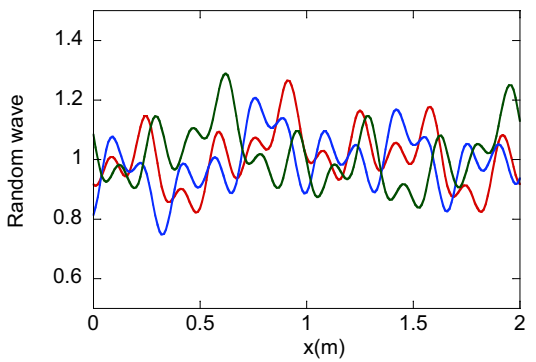

(c) Case 3 (decreasing)

Fig. 10 Example of spatial variation in distributed load

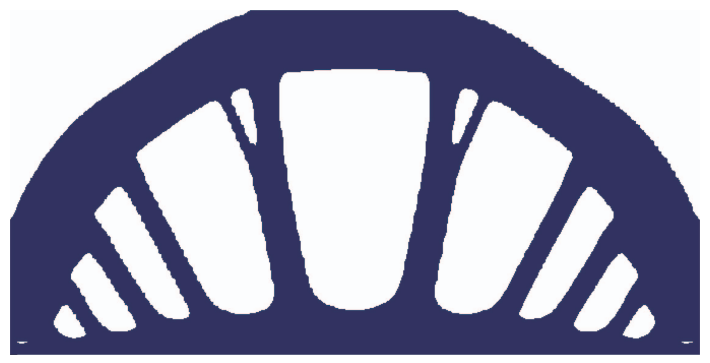

(a) Deterministic

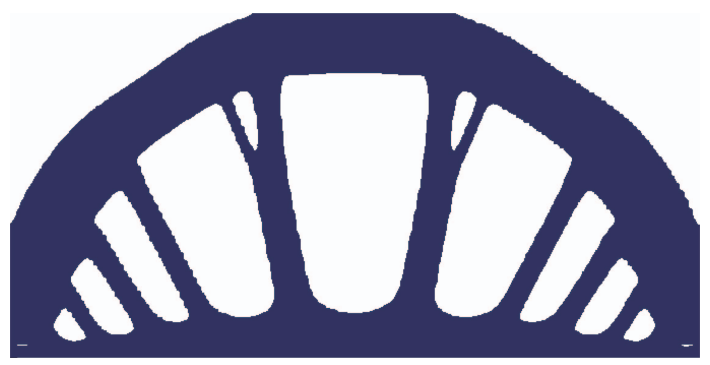

(c) Robust case 2 (increasing)

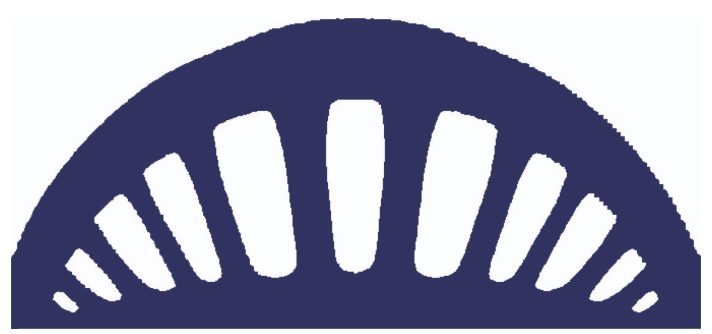

(b) Robust case 1 (constant)

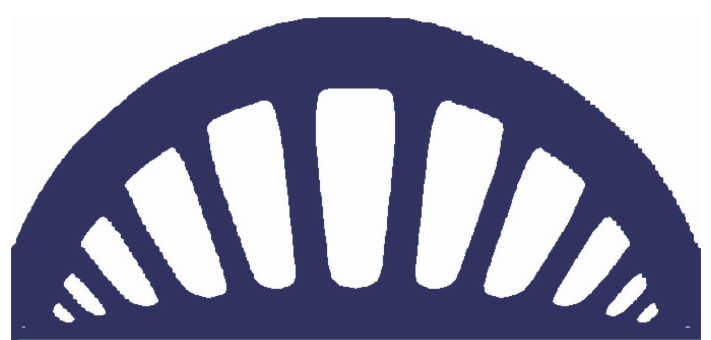

(d) Robust case 3 (decreasing)

Fig. 11 Deterministic and robust optimum configurations

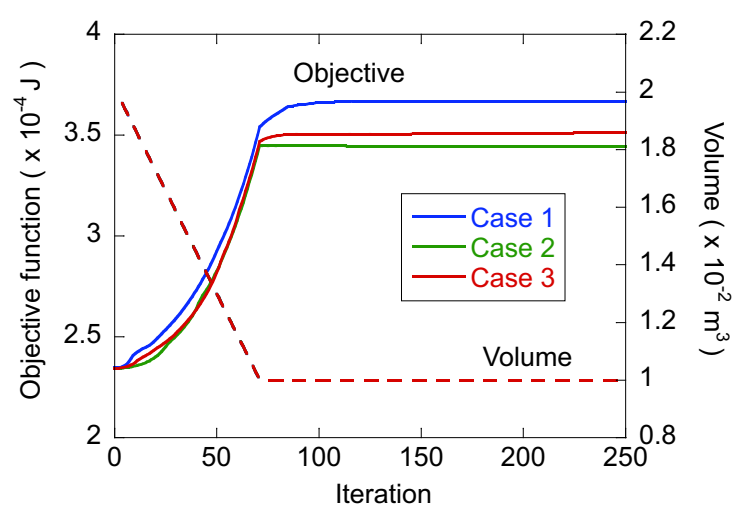

Fig. 12 Convergence history of robust topology optimization

等分布荷重の場合との差異が少なくなるためと考えられる，ケース 3 は，ケース 1 よりもアーチが高いが，柱の 間隔，柱の本数ともにケース 1 とよく似た形態となっている.

次に，各ケースにおける収束履歴を図 12 に示寸. どのケースにおいてもスムーズに収束していることがわかる. また，各ケースにおける目的関数值を表 2 で比較する。いずれの場合においても，目的関数值に大きな差はみら れない，また，体積制約は 5 桁の精度で活性化していることがわかる。 
Table 2 Comparison of deterministic and robust optimum designs

\begin{tabular}{c|cc}
\hline & Objective function $(\mathrm{J})$ & Volume constraint $(\%)$ \\
\hline Deterministic design & $3.4430 \times 10^{-9}$ & 49.996 \\
Robust design: case 1 & $3.6672 \times 10^{-9}$ & 50.003 \\
Robust design: case 2 & $3.4438 \times 10^{-9}$ & 49.996 \\
Robust design: case 3 & $3.5117 \times 10^{-9}$ & 49.996 \\
\hline
\end{tabular}

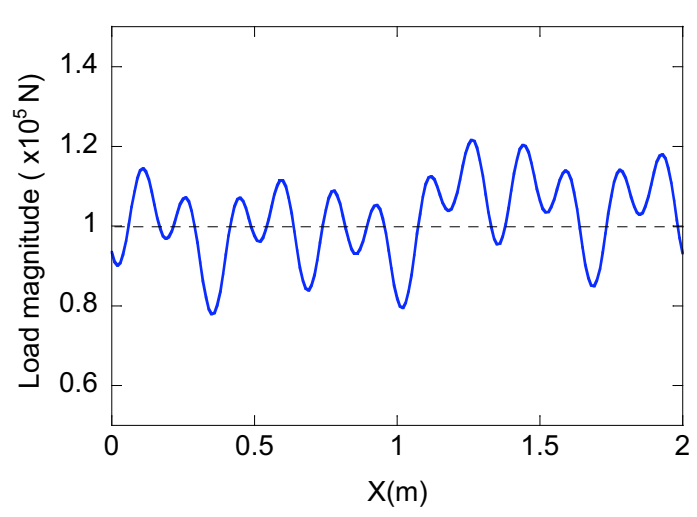

Fig. 13 Applied load with variations

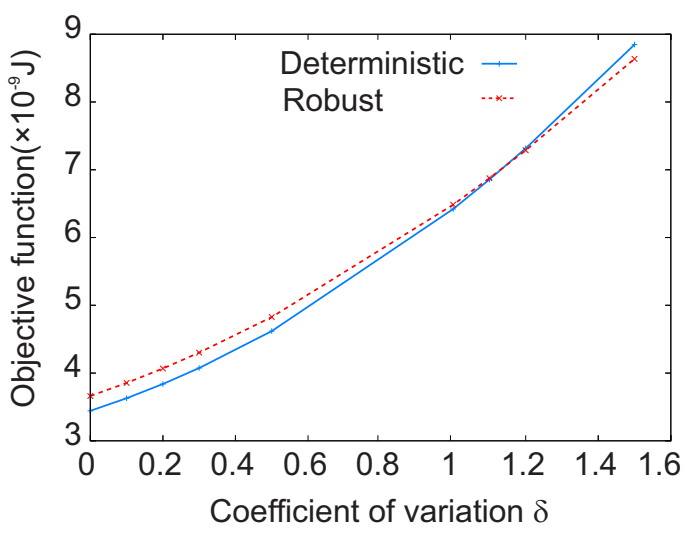

Fig. 14 Change of objective function in coefficient of variation $\delta$

\section{$5 \cdot 2$ ロバスト性の考察}

確定的な最適形態とケース 1 のロバスト形態に対して, 荷重のばらつきを大きくした場合の目的関数值の変化 を比較する. 確率過程にしたがう図 13 に示す荷重分布に対して, 荷重の空間変動に対する変動係数 $\delta$ を変化させ た場合のそれぞれの目的関数の変化を図 14 で比較する. 荷重の変動が大きくなるにつれて，ロバスト形態の方が 確定的最適形態よりも目的関数の值が小さくなることから，ロバスト性を有していると言える.

次に，各ロバスト形態に対して荷重の空間変動の影響を調べるために，確定的な最適形態とロバスト形態に対 して，外力仕事の空間変動に対する波数の影響を考察する.

まず，確定的最適形態とロバスト形態が異なるケース 3 に対して，図 10(c) に示寸荷重の $1 つ$ (変動係数 $\delta=0.1$ ) に対する荷重負荷線上の外力仕事の変動分の分布を図 15(a) に示す。ここで，外力仕事の変動は，変動荷重による 仕事から平均荷重である一様荷重による仕事を差し引いた分である。この外力仕事の変動分のパワースペクトル を図 15(b) に示す．これより，波数の小さな成分の影響が大きいことがわかる．また，この小さな変動に対しては， すべての波数領域において， ロバスト形態の方が確定的最適形態よりも外力仕事が大きく，特に波数の小さな成 分ではその差が顕著である.

これに対して，荷重の変動を大きくした場合 (変動係数 $\delta=0.9)$ の荷重負荷線上の外力仕事の変動分の分布およ びそのパワースペクトルを図 16 に示す，パワースペクトルを見ると，すべての波数領域において，ロバスト形態 の方が確定的最適形態よりも外力仕事が小さくなっている。つまり，ロバスト形態は荷重変動に対するロバスト性 を有していることを示している．特に，波数の小さな成分での差が大きい．波数の小さな変動成分に対してロバス 卜性を確保寸るために，確定的最適形態に比べて，ロバスト最適形態では柱の間隔が等間隔で本数が多くなって いると考えられる.

このことが，変動成分が同じでも位相の異なる荷重に対しても成立するかどうかを調べるために，図 $10(\mathrm{c})$ に示 した他の 2 つの荷重に対する結果を図 17, 図 18 に示す。いずれの荷重でも変動が小さいときは確定最適形態の方 がロバスト形態よりも仕事が小さいが，変動が大きくなると逆転し，波数の小さな領域でその影響が顕著である ことがわかる。

これら 3 つの場合に実際の荷重が異なるために仕事の空間変動は異なっているが，パワースペクトルで比較す ると，お互いによく似ていることがわかる．境界条件の影響を受けるために波数の小さな領域では異なっている が，波数の大きな領域での違いは小さい。これは確率過程を用いてモデル化することの利点でもある. 


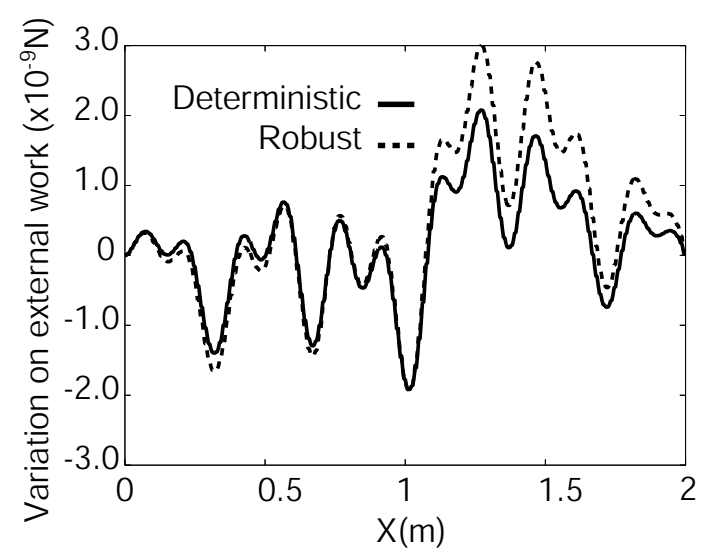

(a) Variation on external work

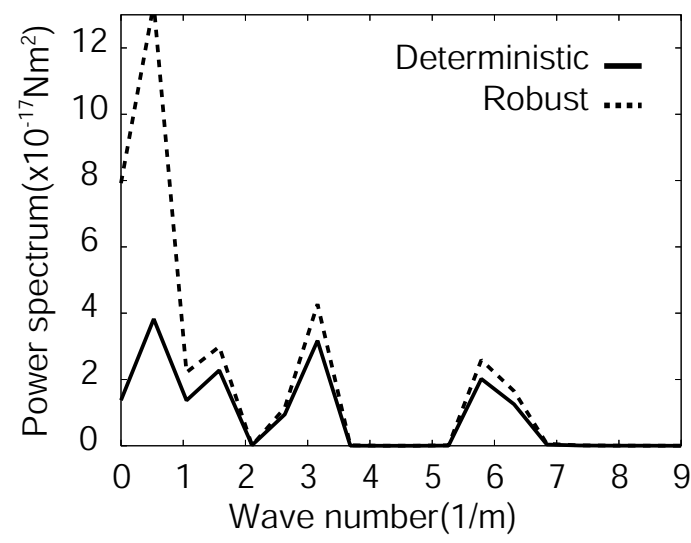

(b) Power spectrum of variation on external work

Fig. 15 Variation on external work in case 3 (decreasing)

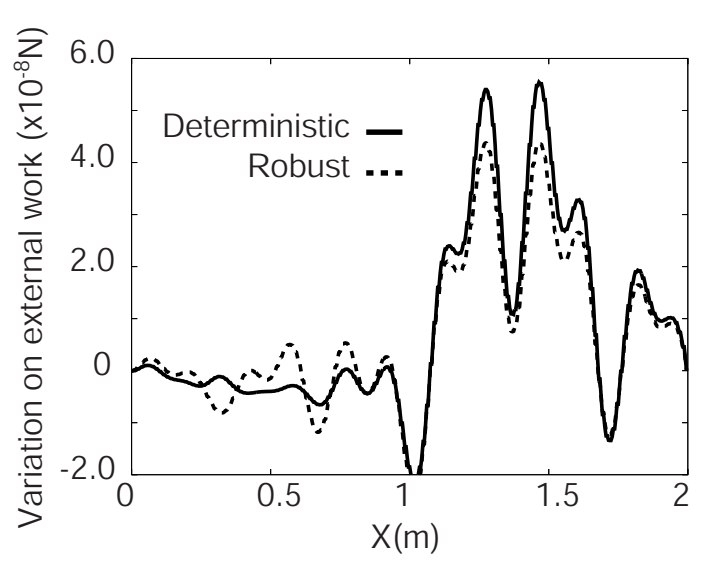

(a) Variation on external work

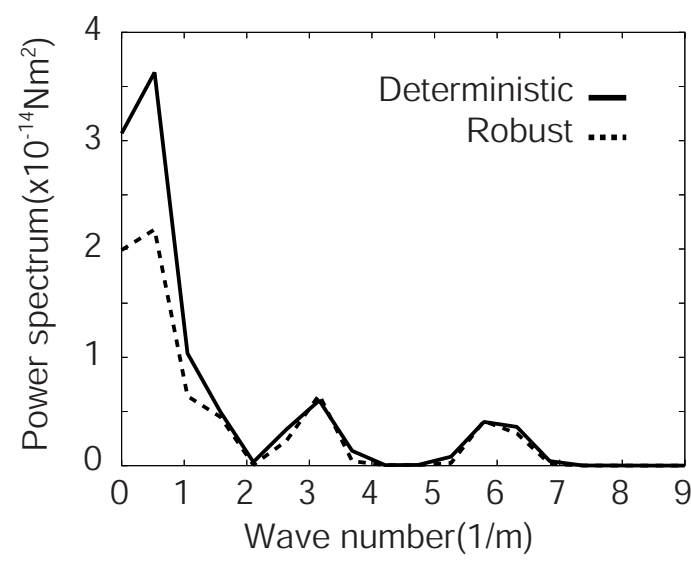

(b) Power spectrum of variation on external work

Fig. 16 Variations on external work for larger load variation $(\delta=0.9)$ in case 3 (decreasing)

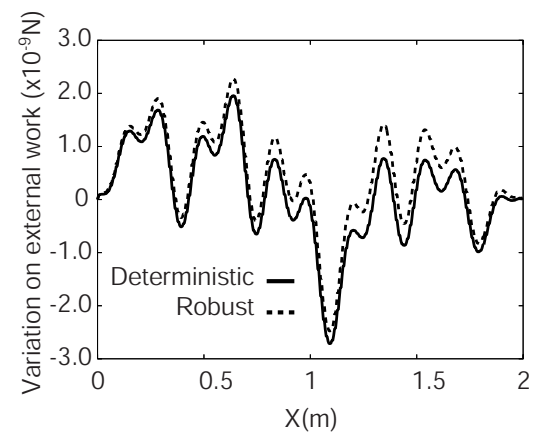

(a) Variation on external work $(\delta=0.1)$

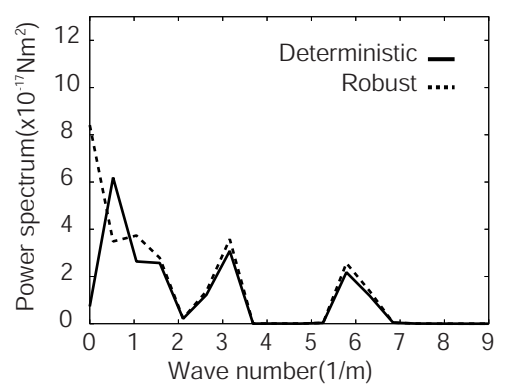

(b) Power spectrum $(\delta=0.1)$

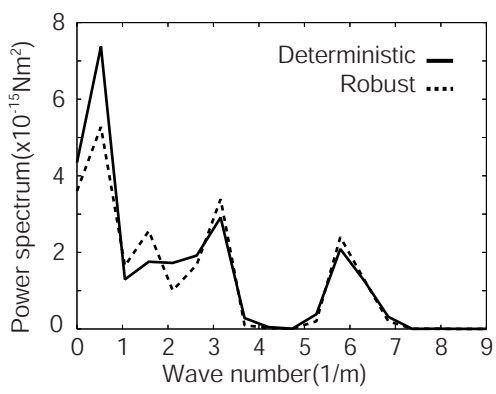

(c) Power spectrum $(\delta=0.9)$

Fig. 17 Variation on external work for second actual load in case 3 (decreasing)

他の荷重ケースに対しても同様の比較を行った，ケース 1 に対する結果を図 19 に，ケース 2 に対する結果を図 20 に示す．上に示したように，同一の空間成分を有する位相の異なる荷重に対して，外力仕事の波数領域での変 動の違いは小さいため, 図 10 の中の 1 つの荷重に対する結果のみを示す.

ケース 1 は荷重の波数に対する変動が一定であるが，外力仕事に対しては波数の小さな領域での影響が大きく なっている.さらに，ケース 1 のロバスト形態はケース 3 のロバスト形態と似ていることから，ケース 3 と同様 に，荷重の変動が大きくなると波数の小さな領域での違いが大きくなることがわかる.

ケース 2 は荷重の波数が大きい領域の変動が大きい場合であり, 外力仕事に対しても同様な傾向がある. ただ し, ケース 2 ではロバスト形態が確定的最適形態と似ているため, 確定設計とロバスト設計の違いは見られない. このことより，確定解は高周波の分布荷重の変動にロバストな形態であるともいえる. 


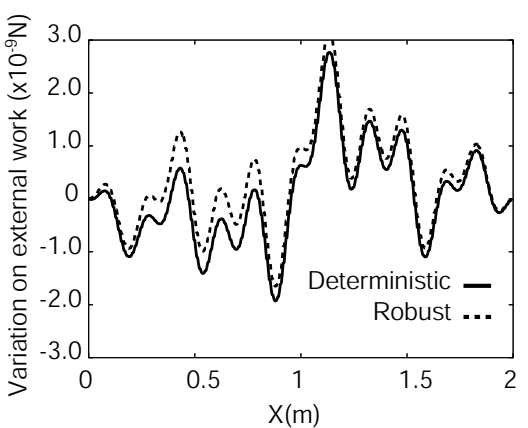

(a) Variation on external work $(\delta=0.1)$

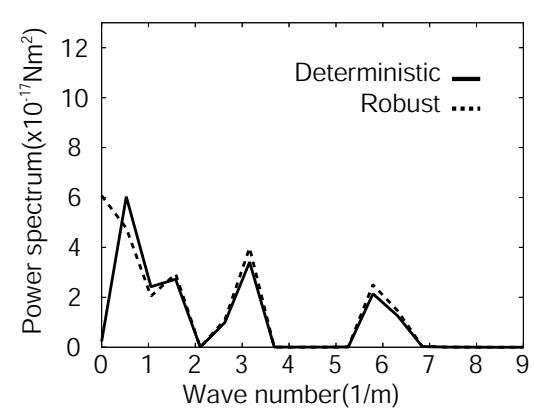

(b) Power spectrum $(\delta=0.1)$

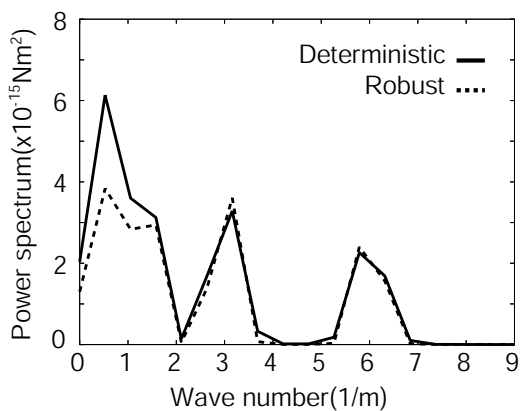

(c) Power spectrum $(\delta=0.9)$

Fig. 18 Variation on external work for third actual load in case 3 (decreasing)

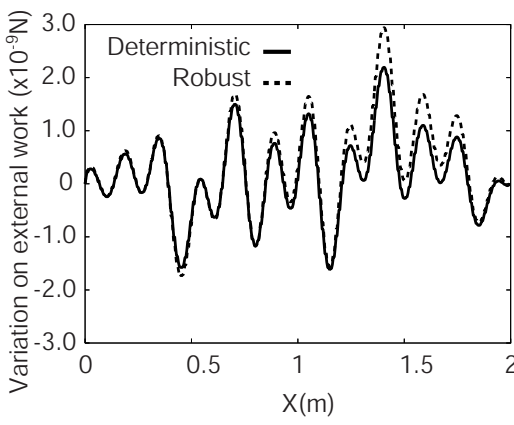

(a) Variation on external work $(\delta=0.1)$

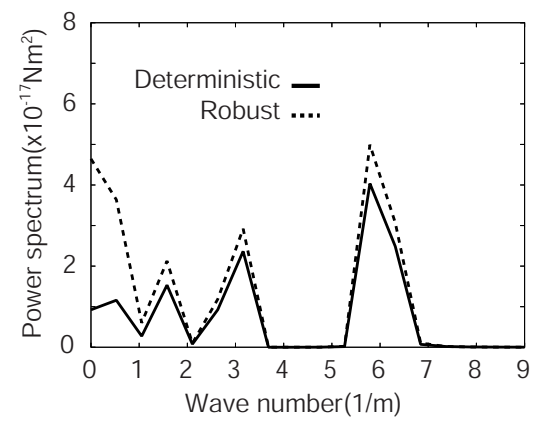

(b) Power spectrum $(\delta=0.1)$

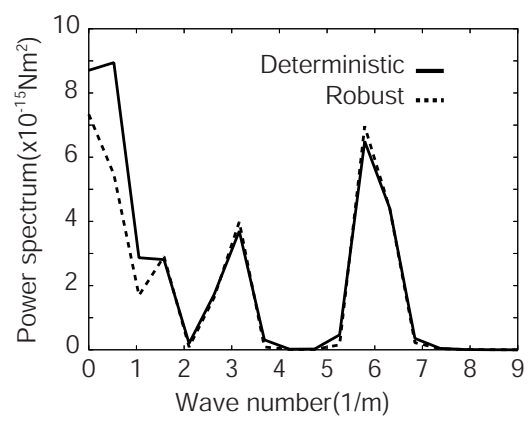

(c) Power spectrum $(\delta=0.9)$

Fig. 19 Variation on external work in case 1 (constant)

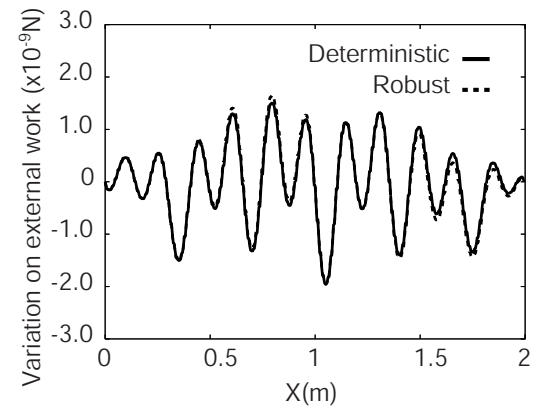

(a) Variation on external work $(\delta=0.1)$

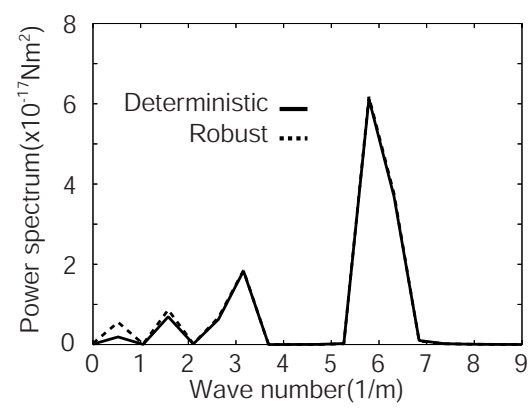

(b) Power spectrum $(\delta=0.1)$

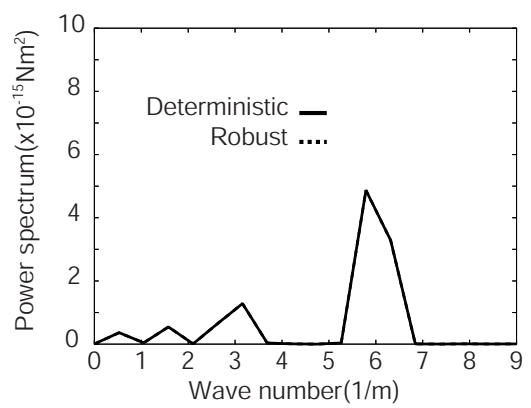

(c) Power spectrum $(\delta=0.9)$

Fig. 20 Variation on external work in case 2 (increasing)

\section{$5 \cdot 3$ 重み係数 $\alpha$ がロバスト形態におよぼす影響}

ロバスト項に関する重み係数 $\alpha$ の設定によって, 最適形態におよぼす変動の影響を定性的に変化させることが できる. そこで, 前節までに示した $\alpha=25$ の場合のほかに， $\alpha=10$ および $\alpha=40$ の場合におけるロバスト最適 形態を，それぞれ，図 21 および図 22 に示寸. これらと図 11 に示した確定的最適形態および $\alpha=25$ の場合の口 バス卜最適形態とを比較する.

波数成分が均一な変動であるケース 1 では， $\alpha=10$ の場合は確定的な最適形態に近いが， $\alpha$ が大きくなるにつ れて柱の本数が増加するとともに柱の間隔が狭くなり，アーチが低くなるとともに太くなるように変化する．低 周波の分布荷重変動が支配的であるケース 3 においても同様の傾向がみられるが，こちらのほうが $\alpha=10$ の場合 でも柱の間隔が狭い形態が得られている。これに対して，波数の多い変動が支配的となるケース 2 では，ロバス 卜最適形態は確定的な最適形態とよく似ていて， $\alpha$ の值に対する変化がほとんどみられない.

これらの荷重ケースにおける $\alpha$ に対するロバスト形態の変化は，低周波の変動がロバスト性に大きく影響し，高 周波の変動はロバスト性への寄与が小さいという前節の結果とも対応している. 


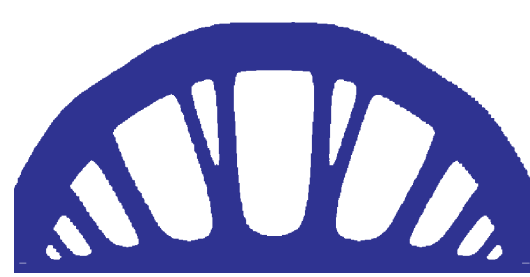

(a) Case 1 (constant)

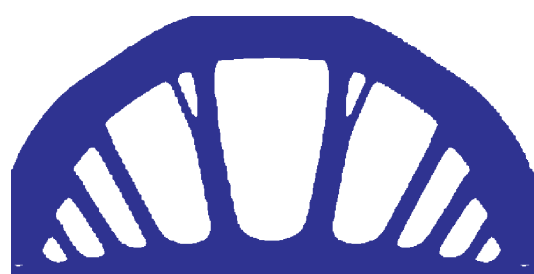

(b) Case 2 (increasing)

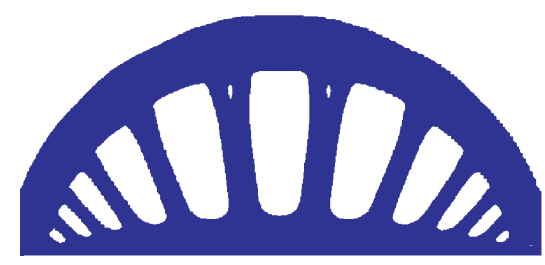

(c) Case 3 (decreasing)

Fig. 21 Robust optimum constration in case of $\alpha=10$

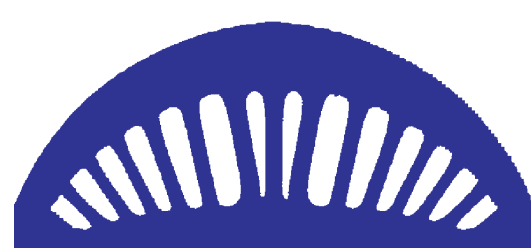

(a) Case 1 (constant)

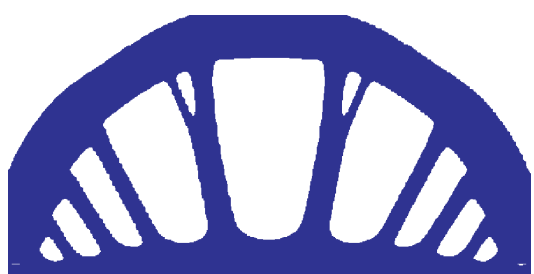

(b) Case 2 (increasing)

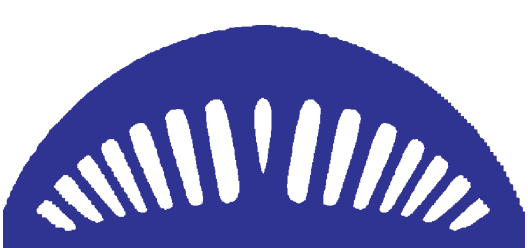

(c) Case 3 (decreasing)

Fig. 22 Robust optimum constration in case of $\alpha=40$

\section{6. 結言}

本研究では, 荷重の空間的な変動に対してロバストな構造形態を求めるためのロバストトポロジー最適設計法 を提案している，ロバスト最適設計問題においては，設計パラメータの空間的変動を定常確率過程を用いてモデ ル化し, 体積制約のもとでコンプライアンスの平均值および標準偏差の重み付き加重和を最小化する問題として 定式化している. トポロジー最適設計法としては，フェーズフィールド法の考え方に基づいた仮想的な界面エネ ルギーを導入することで境界移動と形態変更とを可能としたレベルセット法に基づくトポロジー最適設計法を採 用している。

提案手法の妥当性を明らかにするために，数值計算例を通して，下記のことを明らかにした.

・フェーズフィールド法の考えに基づいたトポロジー最適設計法は，確定的な場合と同様に，ロバスト設計に おいても，明瞭な境界を有する妥当な構造形態を求めることができることを示した.

・確定的なトポロジー最適設計と同様, ロバストトポロジー最適設計においても, 体積制約が活性となる最適 形態になめらかに収束することを示した。

- 外力仕事の空間分布をパワースペクトルを介して波数領域で比較することで，確定的な最適形態とロバスト 最適形態の違いを考察することができることを示した.

・ロバスト項に対する重み係数 $\alpha$ の違いによるロバスト最適形態を比較し，パワースペクトルを介した波数領 域を利用した上記の考察が妥当であることを示した。

今後の課題として，ヤング率などの材料特性の空間変動への拡張や三次元設計問題への拡張があげられる.

\section{謝辞}

本研究の一部に，科研費 (基盤研究 (C) 22560784) の助成を受けた.

文献

(1) A. Ben-Tal, L. El Ghaoui, and A. Nemirovski, Robust Optimization, Princeton, (2009)

(2) H. G. Beyer and B. Sendhoff, "Robust optimization - a comprehensive survey", Computer Methods in Applied Mechanics and Engineering, Vol. 196, No. 33-34 (2007), pp. 3190-3218.

(3) Y. Ben-Haim and I. Elishakoff, Convex Models of Uncertainty in Applied Mechanics, Elsevier Science, (1990)

(4) 平野佑享, 山田崇恭, 小木曽望, 泉井一浩, 西脇眞二, 伊賀淳郎, “レベルセット法に基づく熱構造連成問題のト ポロジー最適設計に対する不確定性を考慮したロバスト設計法”, 日本機械学会論文集 C 編, Vol. 77, No. 773 (2011), pp. 1-13. 
(5) 日野幹雄, “スペクトル解析” (1977), 朝倉書店

（6）中桐滋, 久田俊明, “確率有限要素法 -不確定構造の解析-” (1985), 培風館

(7) R. G. Ghanem and P. D. Spanos, Stochastic Finite Elements, A Spectral Approach, Revised ed. (2003), Dover Publishers

(8) C. A. Schenk, and G. I. Shuëller, Uncertainty Assessment of Large Finite Element Systems (2005), Springer-Verlag

(9) T. Yamada, K. Izui, S. Nishiwaki, and A. Takezawa, "A topology optimization method based on the level set method incorporating a fictitious interface energy", Computer Methods in Applied Mechanics and Engineering, Vol. 199, No. 45-48 (2010), pp. 2876-2891.

(10) M. Y. Wang, X. Wang, and D. Guo, "A level set method for structural topology optimization", Computer Methods in Applied Mechanics and Engineering, Vol. 192, No. 1-2 (2003), pp. 227-246.

(11) G. Allaire, F. Jouve, and A. Toader, "Structural optimization using sensitivity analysis and a level-set method", Journal of Computational Physics, Vol. 194, No. 1 (2004), pp. 363-393.

(12) J. W. Cahn and J. E. Hilliard, "Free energy of a nonuniform system, I. interfacial free energy", The Journal of Chemical Physics, Vol. 28, No. 2 (1958), pp. 258-267.

(13) S. M. Allen and J. W. Cahn, "A microscopic theory for antiphase boundary motion and its application to antiphase domain coarsening", Acta Metallurgica, Vol. 27, No. 6 (1979), pp. 1085-1095.

(14) S. Chen, W. Chen, and S. Lee, "Level set based robust shape and topology optimization under random field uncertainties", Structural and Multidisciplinary Optimization, Vol. 41, No. 4 (2010), pp. 507-524.

(15) A. Cherkaev, Variational Methods for Structural Optimization, (2000), pp. 117-141, Springer-Verlag.

(16) G. Allaire, Shape Optimization by The Homogenization Method, (2002), pp. 189-257, Springer-Verlag.

(17) S. Sundaresan, K. Ishii, and D. R. Houser, "A robust optimization procedure with variations on design variables and constraints", Engineering Optimization, Vol. 24, No. 2 (1995), pp. 101-117.

(18) A. Takezawa, S. Nii, M. Kitamura, and N. Kogiso, "Topology optimization for worst load conditions based on the eigenvalue analysis of an aggregated linear system”, Computer Methods in Applied Mechanics and Engineering, Vol. 200, No. 25-28, (2011), pp. 2268-2281. 